\title{
Ergonomic evaluation of processes and products in the manufacture of upholstery
}

\author{
Patrícia Bhering Fialho ${ }^{\mathrm{a},}{ }^{*}$, Amaury Paulo de Souza ${ }^{\mathrm{b}}$, Luciano José Minette ${ }^{\mathrm{c}}$, José de Castro Silva ${ }^{\mathrm{d}}$ and \\ Luciana Aparecida de Oliveira ${ }^{\mathrm{e}}$ \\ ${ }^{a}$ Federal Center of Technological Education of Minas Gerais - CEFETMG, Santa Rita st.,900, Curvelo, Minas \\ Gerais, Brazil \\ b,c,e Ergonomic Laboratory - Forest Engineering Department, Federal University of Viçosa, Minas Gerais, Brazil. \\ ${ }^{\mathrm{d}}$ Forest Engineering Department, Federal University of Viçosa, Minas Gerais, Brazil
}

\begin{abstract}
This study aimed to perform an ergonomic evaluation of industrial processes and products - upholstered sofas produced in the furniture cluster of Ubá-MG. The used material was collected from two sofas upholstered industries associated with the union of the furniture industries of Ubá region, located in Minas Gerais estate, Brazil. As for the product were evaluated dimensionally 29 upholstered sofas, with 12 being produced by industry "A" and 17 being produced by industry "B". As for the process, were evaluated: the socioeconomic profile of the worker and environmental factors of lighting and noise. The main results of this study showed that the upholstered sofas produced by industries, in general, fulfilled to the recommendations set out in the work in relation to the backrest height and useful seat depth. All the sofas, however, proved to be inadequate in relation to the seat height to the floor and the dimensions of the armrests Regarding environmental aspects, it was observed that in both industries, the activities in most jobs are performed under adverse conditions to the health and safety of workers and nonconformity with the limits set by Brazilian regulatory standard used in this work.
\end{abstract}

Keywords: sofa; furniture industry

\section{Introduction}

In the globalization era, competitiveness and the markets dynamic are hard facts. In the furniture sector, this scenario is not different. One of the used mechanisms to keep the presence and the growth of this segment is the search for quality. In this context, two approaches of the ergonomic action complement each other and are of fundamental importance for the improvement of the efficiency of this sector: the ergonomics of the process and ergonomics of the product.

The ergonomics of the process is aimed at the understanding of the actual conditions of employment, seeking, among other factors, the optimization of the production process, promoting better working conditions and aid in the prevention of accidents and occupational diseases. Its performance is also intended to improve the comfort, safety and welfare of the worker, once that adapting the work and its environment to the individual needs. The ergonomics of the product is related to the application of ergonomic principles in the design or repair of product designs, involving aspects such as anthropometric adaptation, movements compatibility, functionality, comfort, safety, as the provision of clear information and usability. The result of the union between ergonomics and creativity of the designer are the health and satisfaction of the user.

Many furniture designers rarely develop projects guided by the ergonomic precepts. The mistaken view of reducing costs by manufacturers, combined with the lack of largest claiming from consumer and the lack of publications in the area, may be reasons for the failure to consider the ergonomics projects. Among the household furniture, stand out the

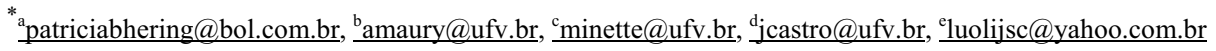


upholstered, present in most Brazilian homes. Despite their importance in daily life, it appears that many of them have ergonomic inadequacies that may affect the health and comfort of the user. Moreover, little is known in academic circles about the production of this furniture.

Therefore, this work had as a general aim to promote an ergonomic evaluation of the manufactured processes and of the upholstered sofas, produced in industries operating in the Local Productive Arrangement (APL) of Uba, MG, aiming at improving the ergonomic quality and consequently, to increase the competitiveness of the industries located in this cluster.

\section{Method}

\subsection{Sampling and data collection}

A The data collection for the development of this research was conducted in two furniture upholstered sofas industries, associated with the Trade Union of Furniture Industries of Uba - Intersind, both located in the city of Uba, Minas Gerais, Brazil.

Each chosen industry for the research has an attendance profile for different population social segments: popular and high. As a means of differentiation, was chosen to call them as Industry "A" and Industry "B".

\subsection{Ergonomic evaluation of the product}

At this stage, was evaluated 12 upholstered sofas from "A" industry and 17 upholstered sofas from "B" industry.

The evaluation criteria were based on ergonomic principles of anthropometric and of security aspects for the user. Data were collected about the following furniture dimensions: height, depth and seat width; backrest height and inclination; armrests height, depth and width. The collected data were compared with the Brazilian technical regulatory standard [1] recommendations; moreover recommendations by Panero and Zelnik [5] and Instituto nacional de tecnologia [2] that were used in the percentiles form.

The dimensions of the furniture were compared with the following anthropometric variables: height popliteal; buttock depth - popliteal, the person seated, hip width, subject seated, elbow to the seat, arms reach, sit, elbow to elbow width, guy sitting comfort and inclination of the trunk.

\subsection{Ergonomic evaluation of the process}

As for the process, were evaluated: the structure and operation of the manufacturing process of upholstered furniture; the socioeconomic profile of the worker and environmental factors of lighting and noise environment. About the noise, were evaluated 6 workstations located in the wood cutting sector from "A" industry and 10 workstations from carpentry from " $\mathrm{B}$ " industry.

The obtained data regarding the noise environment was confronted with the limits set by Regulatory Standard 15 (NR15) - Unhealthy Activities and Operations [6], from the Ministry of Labor and Employment of Brazil.

About the workplace illumination, were evaluated 4 workstations from the wood cutting sector from " $\mathrm{A}$ " industry and 8 workstations from the woodworking sector from " $\mathrm{B}$ " industry. The data regarding to illumination were confronted with the Brazilian standard [2], from the Brazilian Association of Technical Standards (ABNT).

\section{Results e discussion}

\subsection{Ergonomic evaluation of the product}

Through the collection and analysis of data, was observed that the analyzed sofas from industries A and $B$, presented seat height between 41.7 and $52 \mathrm{~cm}$, a width of $10.3 \mathrm{~cm}$. By comparing these values with the maximum height value recommended by Panero and Zelnik [5], $41.0 \mathrm{~cm}$, with values based on anthropometric data of Instituto Nacional de Tecnologia [4] for people with popliteal height percentile $5.35 \mathrm{~cm}$ and percentile $50,39.4 \mathrm{~cm}$, it was found that $100 \%$ of the sofas does not fit in the recommendations of the work, once they exceeded the maximum established values.

About the width of the seat, it was found that $20 \%$ of the upholstered furniture from "A" industry were not in accordance with the Brazilian technical norm [1], since it had seat width less than the minimum recommended by it $(85 \mathrm{~cm}$ for upholstery of two seats and $127 \mathrm{~cm}$ for upholstered of three seats). As for the upholstery from "B" industry, $100 \%$ were in accordance with this standard about seat width. 
The upholstered sofas produced by "B" industry, in general, showed widths, depths and backs of seats values superior to those produced by industry "A". This fact may be related to the target audience of products from " $\mathrm{B}$ " industry, the upper middle class.

By comparing the values of useful depth of the seats with the recommendations of the Brazilian technical norm [1] $(4.0 \mathrm{~cm})$, showed that $75 \%$ of the upholstery sofas from " $A$ " industry and $100 \%$ of the upholstery sofas from " $\mathrm{B}$ " industry fit the standard, once it presented useful seat depth above the minimum established by this standard.

In relation to the height of the armrests, was verified that $89.9 \%$ of the sofas in the " $\mathrm{A}$ " industry and $100 \%$ of " $\mathrm{B}$ " industry does not fit on the recommendation of Brazilian technical norm [1], which the height of the armrests to the seat should present maximum and minimum values of $2.6 \mathrm{~cm}$ and $22.9 \mathrm{~cm}$.

\subsection{Ergonomic evaluation of the process}

Nas duas indústrias, os processos de produção dos estofados são caracterizados pelo baixo nível de automação, com os mesmos tipos de máquinas, além de uso intensivo de mão de obra.

In both industries, the production processes of upholstery sofas are characterized by low level of automation, with the same types of machines, as well as intensive labor force.

The production process of "A" industry is performed in a way that the workstations are grouped, according to the sequence of operation by sectors, in " $\mathrm{B}$ " industry, the production is characterized by the combination of two processes: a cell production and the other is the sequence production.

Workers in both industries showed a low level of education. In the " $\mathrm{A}$ " industry, $10 \%$ of employees had completed high school and in " $\mathrm{B}$ " industry this rate was higher, reaching $34 \%$.

In both industries prevailed $(100 \%)$ the male worker in the sectors of wood processing and in the production of furniture. Feminist work it was prevailed $(100 \%)$ in the sewing sector. Workers in both industries have submitted similar reports and complaints of pain or discomfort. The body regions most affected were the top and bottom of the back, wrists and hands.

In the " $A$ " industry, $47.4 \%$ of workers complained of pain or discomfort occurred in the last twelve months in the lower back (lumbar spine), 34.2\% complained of these symptoms in the upper back and $26.3 \%$ in the wrists and hands.

In the "B" industry, $38 \%$ of workers complained of these symptoms in the wrists and hands, 29.5\% lower back (lumbar spine) and 10.5\% in the upper back.

In the sectors of wood cutting and manufacturing from both industries are the workstations involved with activities that require attention at work on machines fitted with blades or holes. The Brazilian norm [2] determines illuminance between 200 to 500 lux for carpenters whose activities are of sizing, planing, thick grinding, rigging semi precise, bonding, veneering and installation.

Through data analysis, was verified that $50 \%$ of workstations in the " $A$ " industry, whose activities are the same as in carpentry work, were not in accordance with the recommendation of the standard Brazilian norm [2] (minimum of 500 lux), once it varied from 161 to 248 lux. Other workstations in accordance with the standard values were between 719 and 850 lux.

In relation to " $\mathrm{B}$ " industry, the illuminance levels measured in workstations involving carpentry activities ranged from 189 lux to 926 lux. By comparing the illuminance at each workstation with the minimum established standard by Brazilian technical norm [2] (500 lux) was verified that $70 \%$ of the workstations had values less than the standard value established by the standart, not being, therefore, in accordance with it. These illuminance values ranged between 189 and 458 lux. By analyzing the noise equivalent levels measured in workstations in the wood cutting sector of the "A" industry, it was found that in this environment, these levels ranged from $85.5 \mathrm{~dB}(\mathrm{~A})$ to $92.2 \mathrm{~dB}(\mathrm{~A})$.

For a workday of eight hours daily, the maximum permissible exposure is $85 \mathrm{~dB}$ (A), according to NR15 [6]. By comparing the data collected with the value set by the regulation norm, it was verified that $100 \%$ of the equivalent noise levels measured in the cutting wood sector, were above $85 \mathrm{~dB}$ (A), and therefore, not in accordance with the NR15 [6].

In the " $\mathrm{B}$ " industry, the equivalent noise levels in the woodwork sector ranged from 86.0 to $97.8 \mathrm{~dB}$ (A). By comparing the data collected with the value set by this regulation norm, it was verified that all the equivalent noise levels, measured in the woodwork sector, were above $85 \mathrm{~dB}$ (A). And, therefore, not in accordance with NR15 [6].

According to Fundacentro [3] the values above 85 $\mathrm{dB}(\mathrm{A})$ requires immediate actions of correction and control. 
During the research, it was verified that both industries provided earplugs to workers from these sectors. However, it was observed that many workers do not adequately put earplugs in their ears.

\section{Conclusion}

The main conclusions from furniture evaluations were:

The sofas produced by the two industries, in general, fulfilled to the recommendations set out in the work on the backrest height and useful seat depth. All sofas, however, proved to be inadequate in relation to the anthropometrical data and recommendations of authors in relation to the seat height to the floor and the dimensions of the armrests. The upholstery produced by the "B" industry, in general, presented higher dimensions to those produced by "A" industry.

The workers from both industries had similar answers regarding to complaints of pain or discomfort. Regarding environmental aspects, it was observed that, in both industries, the activities, in most workstations, are performed under adverse conditions to safety and health of workers and in noncompliance with the limits set by NR15 [6], regarding assessments of noise. The Most stations showed illuminance levels below the minimum established by the Brazilian norm [1].

\section{Acknowledgements}

The authors are thankful to the Conselho Nacional de Pesquisa e Desenvolvimento Tecnológico - CNPq for its financial assistance, also to the Centro Federal de Educação Tecnológica - CEFETMG and the Universidade Federal de Viçosa - UFV.

\section{References}

[1] Associação brasileira de normas técnicas, NBR 15164: Móveis estofados - sofás. Rio de Janeiro, 2004.

[2] Associação brasileira de normas técnicas, NBR 5413: Iluminância de Interiores. Rio de Janeiro, 1991

[3] Fundacentro - fundação Jorge Duprat Figueiredo de segurança e medicina do trabalho. Norma de Higiene Ocupacional procedimento técnico - Avaliação da Exposição Ocupacional ao Ruído. Ministério do Trabalho: Fundacentro, 2001.

[4] Instituto Nacional de Tecnologia, Manual de aplicação dos dados antropométricos - Ergokit. Rio de Janeiro: INT, 1995. 1 CD-ROM.

[5] J.Panero and M.Zelnik, Dimensionamento humano para espaços interiores. Barcelona: Gustavo Gili, 2002. 320 p

[6] Segurança e medicina do trabalho. 2. ed. atual. São Paulo: Saraiva, 2008. 